\title{
CEP170B Gene
}

National Cancer Institute

\section{Source}

National Cancer Institute. CEP170B Gene. NCI Thesaurus. Code C126611.

This gene may be involved in microtubule organization. 